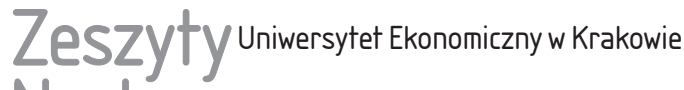 Naukowe
}

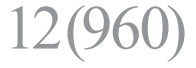

ISSN 1898-6447

Zesz. Nauk. UEK, 2016; 12 (960): 21-39

DOI: 10.15678/ZNUEK.2016.0960.1202

\author{
Aranka Ignasiak-Szulc \\ Wojciech Kosiedowski
}

\section{Gospodarka państw Europy Środkowo-Wschodniej w okresie kryzysowych turbulencji}

\section{Streszczenie}

W artykule omówiono przebieg i rezultaty procesu rozwoju gospodarczego Europy Środkowo-Wschodniej (EŚSW) w kontekście integracji z Unią Europejską, ze szczególnym uwzględnieniem uwarunkowań wynikających z globalnego kryzysu finansowego. Scharakteryzowano gospodarkę EŚSW na tle świata i Europy, a następnie przedstawiono i zinterpretowano zmiany w dynamice wzrostu gospodarczego. Stwierdzono, że zmiany te na świecie i w EŚSW były silnie skorelowane. W opracowaniu zaprezentowano również kształtowanie się sytuacji na rynku pracy w okresie kryzysu.

Z przedstawionych $\mathrm{w}$ artykule badań wynika, że proces konwergencji gospodarczej występował we wszystkich państwach EŚW, co było pozytywnym skutkiem polityki spójności UE. Proces ten był jednak bardzo zróżnicowany, a globalny kryzys spowodował w nim daleko idące, niejednoznaczne zmiany, w tym nawet nieliczne przypadki dywergencji.

Słowa kluczowe: Europa Środkowo-Wschodnia, Unia Europejska, globalny kryzys finansowy, dekoniunktura, wzrost gospodarczy, spójność.

Klasyfikacja JEL: E63, F63, O40.

Aranka Ignasiak-Szulc, Uniwersytet Mikołaja Kopernika w Toruniu, Wydział Nauk Ekonomicznych i Zarządzania, Katedra Integracji Europejskiej i Studiów Regionalnych, ul. Gagarina 13a, 87-100 Toruń,e-mail: aranka@umk.pl

Wojciech Kosiedowski, Uniwersytet Mikołaja Kopernika w Toruniu, Wydział Nauk Ekonomicznych i Zarządzania, Katedra Integracji Europejskiej i Studiów Regionalnych, ul. Gagarina 13a, 87-100 Toruń, e-mail: kosie@umk.pl 


\section{Wprowadzenie}

Państwa Europy Środkowo-Wschodniej (EŚW) tworzą zwarty region międzynarodowy, zlokalizowany między Europą Zachodnią i Federacją Rosyjską, charakteryzujący się podobnym położeniem geopolitycznym, a także wspólnymi, społeczno-historycznymi doświadczeniami i czynnikami rozwojowymi. Do niedawna funkcjonowały w warunkach systemu polityczno-gospodarczego będącego zaprzeczeniem demokracji i wolnego rynku i przez okres prawie półwiecza były pozbawione realnej niepodległości, a trzy z nich (Estonia, Litwa i Łotwa) nie posiadały nawet pozornych, formalnych atrybutów państwowej suwerenności. Nic więc dziwnego, że do dzisiaj różnią się od tzw. starej UE niższym poziomem rozwoju i słabszą międzynarodową pozycją konkurencyjną. Po wejściu do UE zajęły ostatnie pozycje w rankingach Wspólnoty. W związku z opóźnieniem gospodarczym tych państw pojawiły się koncepcje tzw. Europy różnych prędkości, zmierzające do utrwalenia istniejących w UE podziałów. Jak do tej pory koncepcje te nie znajdują potwierdzenia w realnych działaniach, niemniej jednak powodują wiele zamieszania w stosunkach wewnątrz Wspólnoty. Pomimo tego polityka spójności jest kontynuowana, a w jej ramach prowadzone są przedsięwzięcia na rzecz konwergencji społecznej i gospodarczej. Dzięki temu dystans dzielący EŚW od wysoko rozwiniętej Europy Zachodniej powoli, lecz systematycznie się zmniejsza. Ten pozytywny proces objął wszystkie państwa EŚW, chociaż w różnym stopniu. Niestety, nieoczekiwany wybuch globalnego kryzysu finansowego znacznie go zakłócił. Narastające trudności polityczne i gospodarcze Unii stawiają przyszły kształt polityki spójności pod znakiem zapytania.

Niniejsze opracowanie wpisuje się w dyskusję toczącą się wokół zarysowanych wyżej problemów. Jego celem jest identyfikacja i interpretacja zróżnicowanych skutków globalnego kryzysu finansowego dla rozwoju gospodarczego, spójności i konkurencyjności międzynarodowej wschodnich peryferii UE. Zaprezentowanym w artykule badaniom przyświecała hipoteza o dużym zróżnicowaniu reakcji poszczególnych gospodarek krajowych na wywołane przez ten kryzys załamanie koniunktury. Badania te mają charakter wstępnej analizy komparatywnej gospodarek krajowych EŚW w układzie porównań wzajemnych oraz w odniesieniu do całej UE. Przedmiotem porównań są dwa zagadnienia kluczowe dla zrozumienia uwarunkowań procesu budowania w długim okresie międzynarodowej pozycji konkurencyjnej: dynamika wzrostu gospodarczego oraz zmiany w liczbie ludności i wskaźnikach rynku pracy. Pierwsze z tych zagadnień rozpatrzono na podstawie wskaźników wzrostu/spadku PKB, a drugie na podstawie wskaźników sytuacji demograficznej, zatrudnienia i bezrobocia. 


\section{Miejsce Europy Środkowo-Wschodniej w gospodarce europejskiej w okresie przedkryzysowym}

Pojęcie Europy Środkowo-Wschodniej jest w literaturze różnie definiowane [Kosiedowski 2008, s. 77-78]. W niniejszym artykule oznacza ono grupę 11 państw postsocjalistycznych, które aktualnie należą do Unii Europejskiej ${ }^{1}$. W skali światowego systemu gospodarczego EŚS może wydawać się mało znaczącym regionem międzynarodowym. Jej obszar stanowi $0,76 \%$ powierzchni lądowej świata, 10,8\% powierzchni Europy rozumianej jako część świata i 26\% terytorium UE w obecnym jej kształcie, tzn. w składzie 28 państw członkowskich. Podstawowe informacje statystyczne dotyczące tej grupy zawiera tabela 1.

Tabela 1. Powierzchnia, ludność i PKB państw Europy Środkowo-Wschodniej na tle Unii Europejskiej w 2015 r. (ceny bieżące)

\begin{tabular}{|l|c|c|c|c|c|c|}
\hline \multirow{2}{*}{ Wyszczególnienie } & \multirow{2}{*}{$\begin{array}{c}\text { Powierzchnia } \\
\left(\text { w tys. km }{ }^{2}\right)\end{array}$} & $\begin{array}{c}|c| \\
\text { L mln } \\
\text { osób }\end{array}$ & $\begin{array}{c}\text { liczba } \\
\text { osób } \\
\text { na } 1 \mathrm{~km}^{2}\end{array}$ & $\begin{array}{c}\text { w mld } \\
\text { EUR }\end{array}$ & $\begin{array}{c}\text { w mld } \\
\text { PPS }\end{array}$ & $\begin{array}{c}\text { w tys. PPS } \\
\text { per capita }\end{array}$ \\
\cline { 3 - 7 } & 4363,2 & 510,1 & 117 & 14635,2 & 14635,2 & 28,7 \\
\hline EÉ & 1134,8 & 103,3 & 91 & 1150,6 & 1996,4 & 19,3 \\
\hline Bułgaria & 110,9 & 7,2 & 65 & 44,2 & 95,8 & 13,3 \\
\hline Chorwacja & 56,6 & 4,2 & 74 & 43,9 & 70,4 & 16,8 \\
\hline Estonia & 45,2 & 1,3 & 29 & 20,5 & 28,1 & 21,6 \\
\hline Litwa & 65,3 & 2,9 & 44 & 37,1 & 61,4 & 21,2 \\
\hline Łotwa & 64,5 & 2,0 & 31 & 24,4 & 36,6 & 18,3 \\
\hline Polska & 312,7 & 38,0 & 122 & 427,7 & 756,9 & 19,9 \\
\hline Republika Czeska & 78,9 & 10,6 & 134 & 167,0 & 263,4 & 24,8 \\
\hline Rumunia & 238,4 & 19,8 & 83 & 160,4 & 323,5 & 16,3 \\
\hline Słowacja & 49,0 & 5,4 & 110 & 78,1 & 119,4 & 22,1 \\
\hline Słowenia & 20,3 & 2,1 & 103 & 38,6 & 49,0 & 23,3 \\
\hline Węgry & 93,0 & 9,8 & 105 & 108,7 & 191,9 & 19,6 \\
\hline
\end{tabular}

${ }^{\text {a }}$ Stan na 1 stycznia 2016 r.

Źródło: opracowanie własne na podstawie danych Eurostatu (http://ec.europa.eu/eurostat, data dostępu: 12.09.2016).

${ }^{1}$ Są to: przyjęte do Unii Europejskiej 1 maja 2004 r. Estonia, Litwa, Łotwa, Polska, Republika Czeska, Słowacja, Słowenia i Węgry, przyjęte 1 stycznia 2007 r. Bułgaria i Rumunia, oraz przyjęta 1 lipca 2013 r. Chorwacja. 
Państwa EŚW reprezentują stosunkowo nieduży, lecz bardzo zróżnicowany potencjał terytorialny, demograficzny i gospodarczy. Wśród nich jedynie Polska wyróżnia się większym terytorium (6. miejsce w UE). Stosunkowo dużym krajem jest także Rumunia, następnie Bułgaria i Węgry. Pozostałe państwa dysponują obszarem rzędu zaledwie kilkudziesięciu tys. $\mathrm{km}^{2}$. Ludność tego regionu stanowi 20,3\% ludności całej UE, a gęstość zaludnienia jest tutaj znacznie niższa od przeciętnej w UE i bardzo zróżnicowana: najniższa w północnej części (Estonia, Łotwa), najwyższa w części środkowej (Republika Czeska, Polska). Obszar ten, z wyjątkiem położonych w jego zachodniej części Czech i Słowenii, od stuleci charakteryzuje się niższym poziomem rozwoju w porównaniu z Europą Zachodnią. Stosownie do swego ograniczonego udziału w terytorium oraz populacji świata i kontynentu EŚW zajmuje odległe miejsca w gospodarce światowej i europejskiej pod względem wielkości PKB. W 2015 r. wytworzony tutaj PKB stanowił 1,8\% analogicznego wskaźnika światowego, licząc według kursów walut, i 2,3\% według parytetu siły nabywczej, natomiast w stosunku do UE było to odpowiednio 7,9\% i 13,6\%. Największą gospodarką wyróżniała się Polska, wytwarzająca PKB 27 razy większy niż gospodarka najmniejsza - estońska. W przeliczeniu per capita przeciętny w EŚW poziom PKB, obliczony według standardu siły nabywczej, stanowił w 2015 r. 67\% poziomu średniego dla UE. Pod tym względem liderem była Republika Czeska (85\% średniej UE), natomiast ostatnie miejsce zajmowała Bułgaria (46\%). Polska ze wskaźnikiem 69\% zajmowała w omawianej grupie miejsce szóste, wyprzedzając Węgry, Łotwę, Chorwację, Rumunię i Bułgarię.

Funkcjonując w wymiarze historycznym na skrzyżowaniu ważnych szlaków handlowych Wschód-Zachód i Północ-Południe, w sferze aktywnego, gospodarczego, politycznego i kulturowego wpływu Rosji oraz Europy Zachodniej, EŚSW nabrała cech właściwych dla obszarów przejściowych, na których ścierały się wpływy potężnych sąsiadów. Specyficzne położenie tego regionu Europy było powodem jego niezwykle dramatycznej historii, obfitującej w krwawe konflikty, najazdy, rozbiory i wojny. To tutaj rozpoczęły się największe w dziejach ludzkości konflikty zbrojne - obie wojny światowe. Wielokrotnie obszar ten stanowił kartę przetargową w kontynentalnych i globalnych grach politycznych. Nie mogło to pozostać bez wpływu na poziom rozwoju społeczno-gospodarczego, który - jak już wspomniano - bardzo ustępował Zachodowi.

W ostatnich kilkudziesięciu latach położone tutaj państwa przechodziły aż dwie transformacje systemowe. Pierwsza, narzucona zaraz po II wojnie światowej przez ówczesne supermocarstwo - ZSRR, polegała na wprowadzeniu ustroju tzw. realnego socjalizmu (wstępnej fazy ustroju komunistycznego) wraz z systemem gospodarki nakazowo-rozdzielczej, co powodowało znaczne pogłębienie panującego już dawniej zacofania gospodarczego. Drugą transformację zapoczątkowały wydarzenia polityczne, jakie miały miejsce na przełomie lat 80. i 90., najpierw 
w Polsce, a niedługo potem w pozostałych państwach regionu. Dzięki nim zaistniały długo oczekiwane warunki do wprowadzenia gospodarki rynkowej oraz integracji z zachodnimi strukturami polityczno-militarnymi i gospodarczymi: Paktem Północnoatlantyckim (NATO) i Unią Europejską. Konsekwentna realizacja strategii prozachodniej została uwieńczona sukcesem, zanim to jednak nastąpiło, we wszystkich omawianych państwach wystąpił kryzys transformacyjny. Zróżnicowane warunki i możliwości prowadzenia działań antykryzysowych, a także odmienne strategie i orientacje transformacyjne przyjęte w polityce społeczno-gospodarczej poszczególnych państw spowodowały, że głębokość i długość załamania gospodarczego były różne. Dowodzą tego dane zaprezentowane w tabeli 2 . Wynika z nich, że najsprawniej z kryzysem transformacyjnym poradziła sobie Polska, która już w 1992 r. weszła na ścieżkę wzrostu gospodarczego i podąża nią nieprzerwanie aż po dzień dzisiejszy.

W Rumunii i Bułgarii recesja transformacyjna utrzymywała się najdłużej i wystąpiła tam w dwóch etapach. Najgłębszy spadek odnotowały państwa bałtyckie, a szczególnie Łotwa, w której w 1992 r. nastąpił spadek PKB aż o $34,9 \%$. Było to załamanie wyjątkowo głębokie, niespotykane w czasach pokojowych. Większości państw regionu udało się recesję przezwyciężyć w połowie lat 90., a pozostałym kilka lat później, po czym nastąpił okres odrabiania strat i stopniowego niwelowania dystansu wobec państw wysoko rozwiniętych. Upraszczając, można przyjąć, że dekada 1998-2007 to czas bardzo pomyślny dla państw EŚW - ich gospodarki rozwijały się dynamicznie, konkurencyjność międzynarodowa rosła, a pod koniec tego okresu stały się pełnoprawnymi członkami UE. W tej dekadzie wszystkie państwa EŚW realizowały przeciętne tempo wzrostu PKB wyższe niż cała UE, osiągając znaczną poprawę swej sytuacji makroekonomicznej, chociaż w różnym stopniu. Niektóre z nich, zwłaszcza te, które poprzednio odnotowały głębokie załamanie (państwa bałtyckie), osiągnęły nawet imponującą dynamikę ponad $10 \% \mathrm{w}$ skali rocznej. Po raz kolejny rekordowym „skokiem”, tym razem in plus, wyróżniła się Łotwa, osiągając w 2006 r. wzrost PKB na poziomie $11,2 \%$. W sumie po kilkunastu latach pomyślnej koniunktury w ostatnim roku przed kryzysem globalnym (2007 r.) 11 państw regionu wytworzyło łącznie PKB stanowiący 7,1\% według kursów walut i 12,4\% według PPS analogicznego wskaźnika Wspólnoty oraz 2,2\% i 2,6\% - świata.

\section{Konsekwencje globalnego kryzysu finansowego dla rozwoju Europy Środkowo-Wschodniej}

W 2008 r. nieoczekiwanie wybuchł globalny kryzys finansowy. Rozpoczął go krach na rynku kredytów hipotecznych w Stanach Zjednoczonych, 


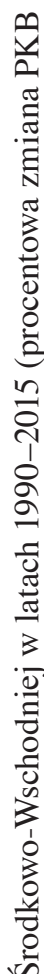

\begin{tabular}{|c|c|c|c|c|c|c|c|c|c|c|c|c|c|c|c|c|c|c|}
\hline$\stackrel{\vec{b}}{\vec{b}}$ & $\stackrel{n}{n}$ & $\stackrel{9}{=}$ & $\vec{p}$ & $\begin{array}{l}0 \\
0 \\
1\end{array}$ & $\hat{a}$ & $\because$ & 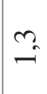 & $\begin{array}{l}0 \\
+\end{array}$ & $\vec{n}$ & $\begin{array}{c}0 \\
\text { m }\end{array}$ & $\begin{array}{l}\text { in } \\
\text { in }\end{array}$ & $\vec{f}$ & $\stackrel{n}{f}$ & $\begin{array}{l}\infty \\
\overbrace{}^{\infty}\end{array}$ & $\begin{array}{l}\infty \\
\dot{\nabla}\end{array}$ & $\stackrel{?}{f}$ & $\begin{array}{l}0 \\
\dot{\nabla}\end{array}$ & ? \\
\hline 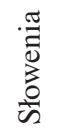 & . & के & $n$ & $\infty$ & n. & $F$ & $\tilde{m}$ & $\begin{array}{l}\infty \\
f\end{array}$ & $\stackrel{r}{r}$ & $\begin{array}{r}\dot{n}_{0} \\
\text { in }\end{array}$ & $\underset{+}{+}$ & $\begin{array}{l}\infty \\
i\end{array}$ & $\stackrel{\infty}{\infty}$ & $\begin{array}{l}\infty \\
i\end{array}$ & $\underset{+}{\dot{\sigma}_{0}}$ & $\begin{array}{l}\stackrel{0}{f} \\
f^{\circ}\end{array}$ & $\tilde{n}$ & જे \\
\hline
\end{tabular}

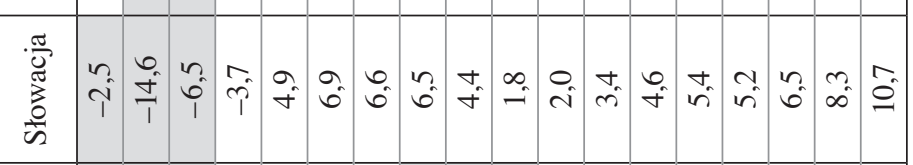

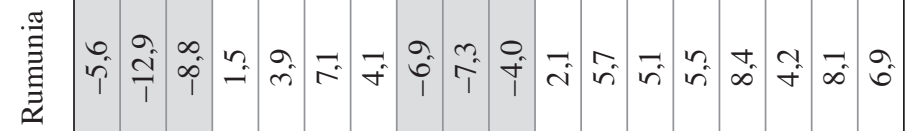

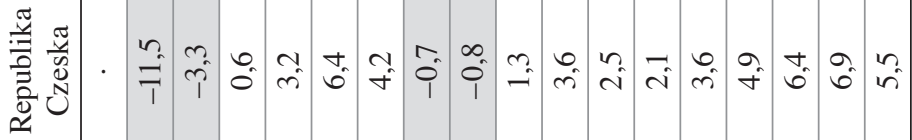

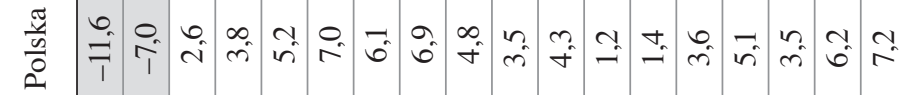

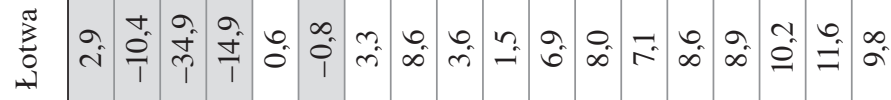

葛

ช্d

现

$£ N$

党. 疍

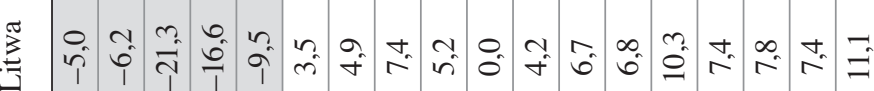

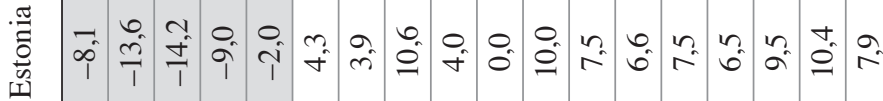

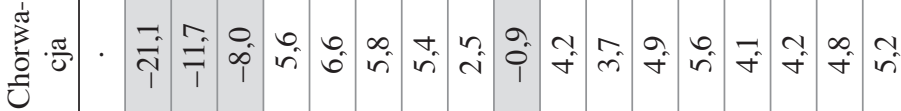

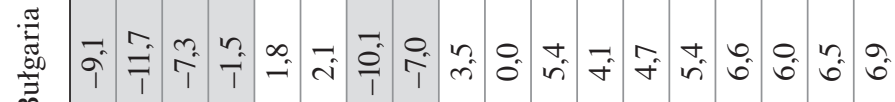

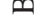

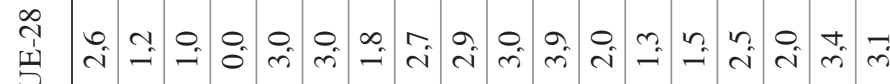
苛 


\begin{tabular}{|c|c|c|c|c|c|c|c|c|c|}
\hline$\stackrel{\substack{c \\
\infty}}{\sum^{\infty}}$ & $\hat{\sigma}$ & $\begin{array}{l}0 \\
0 \\
1\end{array}$ & $\hat{0}$ & $\stackrel{\infty}{-}$ & $\stackrel{F}{7}$ & 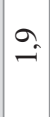 & $\vec{m}$ & $\hat{i}$ & \\
\hline $\begin{array}{l}\frac{\pi}{\tilde{0}} \\
\frac{\tilde{0}}{0} \\
\frac{\overrightarrow{0}}{\Delta}\end{array}$ & $\stackrel{m}{m}$ & $\stackrel{\infty}{\uparrow}$ & $\stackrel{\simeq}{=}$ & $\begin{array}{l}0 \\
0\end{array}$ & $\hat{i}$ & $\Rightarrow$ & $\vec{m}$ & $\stackrel{m}{i}$ & \\
\hline $\begin{array}{l}\frac{\pi}{0} \\
\frac{\pi}{3} \\
\frac{0}{\hbar} \\
\frac{\pi}{n}\end{array}$ & $\begin{array}{l}\sigma_{0} \\
\text { in }\end{array}$ & $n$ & $\vec{n}$ & $\begin{array}{c}\infty \\
i\end{array}$ & $\stackrel{n}{-}$ & $\stackrel{\sigma_{0}}{-}$ & in & $\begin{array}{l}0 \\
\dot{m}\end{array}$ & \\
\hline$\underset{\Xi}{\stackrel{\sigma \Xi}{\Xi}}$ & $\begin{array}{l}n \\
\infty\end{array}$ & $\vec{T}$ & $\begin{array}{l}\infty \\
0 \\
i \\
1\end{array}$ & $=$ & 0 & $n^{n}$ & i. & $\infty$ & \\
\hline 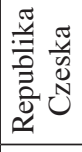 & $\bar{i}$ & $\stackrel{\infty}{+}$ & $\stackrel{m}{i}$ & i & $\begin{array}{l}\infty \\
0 \\
0 \\
1\end{array}$ & $\begin{array}{l}n \\
0 \\
0 \\
1\end{array}$ & $\bar{i}$ & $\stackrel{n}{f}$ & \\
\hline$\frac{\frac{\pi}{4}}{0}$ & ले & $\begin{array}{l}\infty \\
i\end{array}$ & $\begin{array}{l}0 \\
r^{\prime}\end{array}$ & $\begin{array}{l}0 \\
\text { in }\end{array}$ & $\stackrel{0}{-}$ & $\stackrel{?}{=}$ & 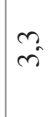 & $\begin{array}{l}0 \\
\text { ri }\end{array}$ & \\
\hline لِّ & r̂ & $\stackrel{m}{\stackrel{2}{+}}$ & pi & స̂. & $\begin{array}{l}0 \\
\dot{f}\end{array}$ & $\begin{array}{c}0 \\
\text { ri }\end{array}$ & $\stackrel{t}{i}$ & $\vec{i}$ & \\
\hline 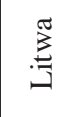 & $\infty$ & $\begin{array}{l}\infty \\
\pm \\
+\end{array}$ & $\stackrel{0}{-}$ & $\begin{array}{l}0 \\
0\end{array}$ & $\begin{array}{l}\infty \\
\dot{m}^{n}\end{array}$ & $\tilde{n}$ & $\stackrel{0}{\circ}$ & 0 & \\
\hline 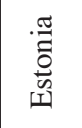 & ? & $\stackrel{\tilde{I}}{+}$ & $\begin{array}{l}n \\
i\end{array}$ & $\begin{array}{l}0 \\
r\end{array}$ & $\begin{array}{l}n \\
\text { nn }\end{array}$ & $\stackrel{0}{-}$ & ते & $\Rightarrow$ & \\
\hline 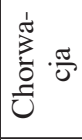 & $\vec{i}$ & $\underset{T}{\nabla_{n}}$ & 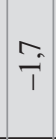 & $\begin{array}{l}n \\
0 \\
1\end{array}$ & ָ̃ & 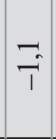 & $\dot{0}_{0}^{+}$ & $\stackrel{0}{-}$ & \\
\hline 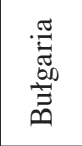 & $\begin{array}{l}\infty \\
\text { in }\end{array}$ & $\stackrel{N}{\underset{y}{1}}$ & $\overrightarrow{0}$ & $\underset{-1}{0}$ & $\begin{array}{c}n \\
0\end{array}$ & $\stackrel{?}{=}$ & $\stackrel{n}{=}$ & $\stackrel{\circ}{\circ}$ & \\
\hline $\begin{array}{l}\stackrel{\infty}{\sim} \\
1 \\
\end{array}$ & $\theta_{0}^{+}$ & $\stackrel{+}{+}$ & $\overrightarrow{\mathrm{i}}$ & $\approx$ & $\begin{array}{l}n \\
0 \\
1\end{array}$ & ஸे & $\because$ & ה & \\
\hline$\frac{y}{0}$ & 文 & 尺े & 응 & $\overline{\bar{D}}$ & $\frac{N}{\delta}$ & $\frac{m}{\tilde{\delta}}$ & ণ & 응 & \\
\hline
\end{tabular}


w tym zwłaszcza tzw. kredytów subprime, które w latach poprzednich rosły w zawrotnym tempie ${ }^{2}$. W rezultacie cały sektor finansowy uległ destabilizacji. Okoliczności, które doprowadziły do tych wydarzeń, zostały szeroko opisane w literaturze (zob. [Soros 2009, s. 157-170]). W zglobalizowanej gospodarce zjawisko to bardzo szybko rozprzestrzeniło się na cały świat i już w tym samym roku wystąpiło w UE oraz EŚSW. Kryzys dokonał spustoszenia w finansach publicznych, powodując duży wzrost deficytu budżetowego i długu publicznego. Szczęśliwie w państwach EŚSW sytuacja w tym zakresie była znacznie lepsza niż w tzw. starej Unii, gdzie zadłużenie osiągnęło poziom zagrażający funkcjonowaniu strefy euro. Turbulencje w sektorze finansowym przeniosły się do sfery realnej: zmniejszył się wolumen produkcji, obniżyły się dochody ludności i przedsiębiorstw, spadł popyt inwestycyjny i konsumpcyjny. W takich warunkach nie mogło być mowy o efektywnym działaniu mechanizmu rynkowego. Doszło do spowolnienia wzrostu gospodarczego, a następnie recesji, po czym nastąpił trwający w zasadzie aż do dzisiaj długi okres dekoniunktury, w którym słaby wzrost był przerywany kolejnymi recesjami. Musiało to spowodować zaburzenia na rynku pracy: w UE liczba bezrobotnych wzrosła z 16,7 mln osób w 2008 r. do 26,3 mln w 2013 r. (maksimum), a więc o ponad 50\%. Tak duże marnotrawstwo najcenniejszej formy kapitału, jaką jest kapitał ludzki, wywołało napięcia i protesty społeczne, skierowane przeciwko machinacjom zglobalizowanego sektora finansowego oraz nieradzącym sobie w tej sytuacji władzom rządowym. W ostatnim czasie do tych problemów doszedł nieoczekiwany bardzo wysoki napływ uchodźców i imigrantów ekonomicznych. Dochodzi do zderzania się interesów poszczególnych państw członkowskich Wspólnoty, starających się przede wszystkim realizować swoje partykularne cele, nie zawsze zgodne z interesem całej Wspólnoty. Obniżyła się pozycja UE na arenie światowej. Wszystko to budzi coraz większe obawy o stan bezpieczeństwa Wspólnoty, zarówno ekonomicznego (zwłaszcza w konfrontacji z agresywną konkurencją azjatycką), jak i socjalnego (szczególnie w kontekście postępującego starzenia się ludności i niewydolności systemów zabezpieczenia społecznego). Kontynent europejski staje się niespokojny. Jego przyszłość w opinii coraz bardziej tą sytuacją zaniepokojonych Europejczyków staje się niepewna (zob. [Giddens 2014]).

${ }^{2}$ Kredyty subprime to produkt finansowy wprowadzony w latach 80 . w celu umożliwienia biedniejszej ludności zakupu domu lub mieszkania. Oferowano je mniej wiarygodnym klientom (o niskich dochodach, bez stałej pracy, nawet takim, którzy nie spłacili wcześniejszych zobowiązań). Jako bardziej ryzykowne były wyżej oprocentowane, ale zmanipulowane zachęty promocyjne powodowały, że cieszyły się wysokim i szybko rosnącym popytem. Ich wartość w USA w 1999 r. wynosiła ok. 160 mld USD, w 2006 r. 600 mld USD, a w marcu 2007 r. już 1360 mld USD (dane Systemu Rezerwy Federalnej - FED). 
Konkurencyjność międzynarodowa UE, a wraz z nią EŚW, która już dawniej pozostawiała wiele do życzenia, w latach globalnego kryzysu finansowego znacznie się pogorszyła. Dowodzą tego dane przedstawione w tabeli 3, pokazujące tendencję spadkową udziału w światowym PKB wszystkich członów tzw. triady (UE, USA i Japonii), w przeciwieństwie do Chin, które swoją pozycję bardzo poprawiły i zajęły w 2015 r. pierwsze miejsce na w świecie. Tendencja ta notowana jest już od co najmniej 20 lat, a w okresie ostatniego kryzysu uległa znacznemu przyspieszeniu. Udział EŚSW w gospodarce światowej również się obniżył, chociaż w stopniu wyraźnie mniejszym niż w przypadku UE. O słabnącej konkurencyjności Wspólnoty świadczą także wskaźniki bezrobocia - stopa bezrobocia w UE, wynosząca w pierwszym roku kryzysowym 7\%, w latach następnych znacznie wzrosła i pomimo pewnej poprawy w ostatnich latach pozostaje na poziomie wyższym niż w 2008 r. (w 2015 r. wynosiła 9,4\%). Na podstawie analizy danych Międzynarodowego Funduszu Walutowego [IMF 2016] stwierdzić można, że w USA, Japonii i w Chinach sytuacja pod tym względem była znacznie lepsza (stopa bezrobocia w USA w 2008 r. wynosiła 5,8\%, a w 2015 r. 5,3\%, w Japonii odpowiednio 4\% i 3,4\%, w Chinach odpowiednio 4,2\% i 4,1\%).

Tabela 3. Udział gospodarki Europy Środkowo-Wschodniej w gospodarce światowej na tle triady i Chin w latach 2007 i 2015 (\% PKB według PPP)

\begin{tabular}{|l|c|c|}
\hline \multicolumn{1}{|c|}{ Wyszczególnienie } & 2007 & 2015 \\
\hline Świat & 100 & 100 \\
\hline EŚW & 2,6 & 2,3 \\
\hline UE-28 & 20,9 & 16,9 \\
\hline USA & 18,4 & 15,8 \\
\hline Japonia & 5,4 & 4,3 \\
\hline Chiny & 11,4 & 17,1 \\
\hline
\end{tabular}

Źródło: opracowanie własne na podstawie danych IMF (www.imf.org, data dostępu: 12.09.2016).

Dynamikę zmian PKB pokazują dane zaprezentowane w tabeli 2. Jak z nich wynika, 2007 r. był ostatnim, w którym wszystkie państwa EŚW osiągnęły przyrost realnego PKB. W następnym roku dwa z nich (Estonia i Łotwa) weszły w stan recesji. Najgorszy okazał się jednak 2009 r., w którym państwa EŚW, podobnie jak cała UE z jednym tylko wyjątkiem - Polski, pogrążyły się w kryzysie. Najgłębsze załamanie gospodarcze wystąpiło w państwach bałtyckich (Łotwie, Estonii i Litwie), które w poprzednich latach osiągnęły bardzo wysoką dynamikę rozwoju, zyskując sobie miano „tygrysów bałtyckich”. Najbardziej ucierpiała Łotwa, w której kryzys panował przez trzy kolejne lata. Pod względem długości kryzysu bardzo negatywnie wyróżniła się natomiast Chorwacja, w której spadek PKB 
trwał nieprzerwanie przez sześć kolejnych lat, aż do 2015 r. W kolejnych dwóch latach kryzys w UE udało się przezwyciężyć, lecz w niektórych państwach EŚW trwał on nadal: w 2010 r. na Łotwie, w Chorwacji i Rumunii, w 2011 r. już tylko w Chorwacji. Stosunkowo korzystną w tych latach dynamikę wzrostu odnotowały Polska, Słowacja i Estonia. Niestety 2012 r. przyniósł drugą falę dekoniunktury: PKB całej Unii spadł o 0,4\%, a w EŚW zjawisko to miało miejsce w czterech państwach: Słowenii, Chorwacji, Republice Czeskiej i na Węgrzech. Kolejne dwa lata przyniosły pewną, lecz ograniczoną poprawę: w 2013 r. gospodarka UE była właściwie w stanie stagnacji, a w trzech państwach EŚW (Słowenii, Chorwacji i Republice Czeskiej) nadal panował kryzys. Dopiero 2014 r. okazał się bardziej pomyślny: UE osiągnęła 1,5\% wzrost PKB, a gospodarki EŚW rozwijały się nawet nieco szybciej, tylko Chorwacja nadal pozostawała w stanie kryzysu. Jeszcze korzystniejszy okazał się 2015 r., w którym wszystkie państwa EŚW, po raz pierwszy od 2007 r., odnotowały wzrost PKB. Zwraca uwagę fakt, że dynamika zmian PKB była w poszczególnych państwach bardzo zróżnicowana ${ }^{3}$. Odnotowane w ostatnich trzech latach ożywienie było stosunkowo silniejsze w Republice Czeskiej, Polsce, Słowacji i na Węgrzech, natomiast słabsze - w państwach bałtyckich i Bułgarii, a w Chorwacji wystąpiły dopiero pierwsze jego oznaki [Sytuacja gospodarcza... 2016]. Oznacza to, że państwa EŚW prowadziły różną politykę społeczno-gospodarczą, ukierunkowaną raczej liberalnie (państwa bałtyckie) lub etatystycznie (np. Republika Czeska, Węgry).

Pojęciem bardziej precyzyjnym niż kryzys jest recesja, która oznacza spadek PKB w ciągu co najmniej dwóch następujących po sobie kwartałów [Recession in the EU-27.. 2009]. Dane do analizy tego zjawiska za okres pierwszej, najgroźniejszej fali kryzysu (2008-2009) zestawiono w tabeli 4. Wynika z nich, że największe nasilenie recesji przypadło na pięć kolejnych kwartałów: od II kw. 2008 r. do II kw. 2009 r.

Państwa EŚW wykazały bardzo zróżnicowaną odporność na kryzys globalny [The Impact... 2010, s. 85-96]. Najbardziej wrażliwe okazały się gospodarki łotewska i estońska, które w stan recesji weszły najwcześniej w całej Unii, już w I kw. 2008 r. W tym samym czasie spadek PKB odnotowała również Słowacja, ale w tym przypadku nie może być mowy o recesji, ponieważ dotyczył on tylko jednego kwartału. W państwach bałtyckich recesja nie tylko pojawiła się najwcześniej, lecz także utrzymywała się bardzo długo (w Estonii i Łotwie przez siedem kolejnych kwartałów). Dla gospodarki łotewskiej najgorszy okazał się I kw. 2009 r., gdy osiągnęła rekordowy spadek o 12\% w ciągu zaledwie trzech miesięcy. Estonia najtrudniejszy okres przeżyła na przełomie lat 2008/2009. W trzecim z państw bałtyckich - Litwie, recesja rozpoczęła się później (III kw. 2008 r.)

${ }^{3}$ Największa różnica we wskaźnikach wzrostu wystąpiła w 2009 r.: od -14,8\% na Litwie do $2,8 \%$ w Polsce. 
Tabela 4. Tempo wzrostu/spadku PKB państw Europy Środkowo-Wschodniej* w latach 2007-2010 (kwartał do kwartału ub., w \%)

\begin{tabular}{|l|c|c|c|c|c|c|c|c|}
\hline \multirow{2}{*}{ Wyszczególnienie } & \multicolumn{4}{|c|}{2008} & \multicolumn{4}{c|}{2009} \\
\cline { 2 - 9 } & \multicolumn{4}{|c|}{ kwartał } & \multicolumn{4}{c|}{ kwartał } \\
\cline { 2 - 9 } & I & II & III & IV & I & II & III & IV \\
\hline UE & 0,6 & $-0,3$ & $-0,6$ & $-1,9$ & $-2,4$ & $-0,3$ & 0,3 & 0,3 \\
\hline Bułgaria & 1,5 & 1,3 & 1,4 & 0,6 & $-6,3$ & 0,0 & $-0,1$ & $-0,2$ \\
\hline Estonia & $-2,2$ & $-1,0$ & $-2,6$ & $-5,9$ & $-5,6$ & $-3,6$ & $-1,1$ & 1,0 \\
\hline Litwa & 1,0 & 0,4 & $-1,8$ & $-1,2$ & $-11,5$ & $-2,1$ & $-0,1$ & $-1,1$ \\
\hline Łotwa & $-4,1$ & $-2,4$ & $-1,1$ & $-3,1$ & $-12,0$ & $-2,0$ & $-3,7$ & 0,1 \\
\hline Polska & 1,4 & 0,7 & 0,8 & $-0,4$ & 0,4 & 0,6 & 0,4 & 1,5 \\
\hline Republika Czeska & 0,3 & 0,7 & 0,2 & $-0,9$ & $-3,6$ & $-0,5$ & 0,5 & 0,4 \\
\hline Rumunia & 3,6 & 1,6 & $-0,1$ & $-2,2$ & $-4,8$ & $-1,4$ & 0,9 & $-1,4$ \\
\hline Słowacja & $-1,4$ & 1,0 & 1,2 & 0,6 & $-7,6$ & 1,1 & 1,2 & 1,4 \\
\hline Słowenia & 1,7 & 0,7 & 0,2 & $-3,3$ & $-6,0$ & $-0,6$ & 0,4 & 0,0 \\
\hline Węgry & 1,2 & $-0,2$ & $-1,0$ & $-2,1$ & $-3,2$ & $-1,3$ & $-0,8$ & 0,1 \\
\hline
\end{tabular}

* bez Chorwacji, dla której brak danych.

Uwaga: kolorem szarym zaznaczono spadek PKB.

Źródło: opracowanie własne na podstawie danych Eurostatu (http://ec.europa.eu/eurostat, data dostępu: 12.09.2016).

i trwała krócej - cztery kwartały, ale pod względem głębokości dorównywała Łotwie (11,5\% spadku PKB w I kw. 2009 r.). Z pozostałych państw EŚW uwagę zwracają Węgry, gdzie recesja nie była wprawdzie zbyt głęboka, lecz trwała długo - przez sześć kolejnych kwartałów (od II kw. 2008 r. do III kw. 2009 r.). Najlepszą sytuacją cieszyła się Polska, gdzie spadek PKB, i to bardzo mały, miał miejsce tylko w jednym kwartale (IV kw. 2008 r.).

Zróżnicowanie dynamiki wzrostu gospodarczego znalazło odbicie w przesunięciach PKB per capita wytworzonego w tych państwach w stosunku do średniej UE. Dane ukazujące te przesunięcia pozwalają ocenić proces konwergencji, tzn. wyrównywania się poziomu rozwoju państw członkowskich UE (zob. tabela 5).

W okresie przed kryzysem globalnym państwa EŚW znacznie poprawiły swoją pozycję w stosunku do średniej UE. Największy sukces odniosły państwa bałtyckie, a szczególnie Estonia, która w 1995 r. odnotowała poziom 38\% średniej UE, a w 2007 r. już 68\%, tj. wzrost o 30 pkt proc. Tak niebywały postęp w ciągu zaledwie 12 lat należy do największych osiągnięć w skali całej UE i jest porównywalny tylko z wcześniejszym tzw. cudem celtyckim, czyli wyjątkowym awansem gospodarki irlandzkiej. Znacznie poprawiły swoją pozycję również Łotwa i Litwa, natomiast najmniejszy postęp w tym zakresie odnotowały Bułgaria i Rumunia. Kryzys finansowy i następujące po nim lata słabej koniunktury przyniosły istotną 
Tabela 5. Wskaźnik spójności gospodarek Europy Środkowo-Wschodniej z Unią Europejską (PKB PPS per capita w stosunku do średniej UE)

\begin{tabular}{|l|c|c|c|c|c|c|}
\hline \multirow{2}{*}{ Wyszczególnienie } & \multirow{2}{*}{1995} & \multirow{2}{*}{2007} & \multirow{2}{*}{2015} & \multicolumn{3}{|c|}{ Zmiana w pkt proc. } \\
\cline { 5 - 7 } & & & & $1995-2007$ & $2008-2015$ & $1995-2015$ \\
\hline UE & 100 & 100 & 100 & $\times$ & $\times$ & $\times$ \\
\hline Bułgaria & 36 & 42 & 46 & 6 & 4 & 10 \\
\hline Chorwacja & 49 & 61 & 58 & 12 & -3 & 9 \\
\hline Estonia & 38 & 68 & 74 & 30 & 6 & 36 \\
\hline Litwa & 34 & 60 & 74 & 26 & 14 & 40 \\
\hline Łotwa & 31 & 60 & 64 & 29 & 4 & 33 \\
\hline Polska & 42 & 53 & 69 & 11 & 16 & 27 \\
\hline Republika Czeska & 71 & 83 & 85 & 12 & 2 & 14 \\
\hline Rumunia & 39 & 41 & 57 & 2 & 16 & 18 \\
\hline Słowacja & 50 & 67 & 77 & 17 & 10 & 27 \\
\hline Słowenia & 69 & 87 & 83 & 18 & -4 & 14 \\
\hline Węgry & 56 & 61 & 68 & 5 & 7 & 12 \\
\hline
\end{tabular}

Uwaga: kolorem szarym zaznaczono przypadki dywergencji.

Źródło: opracowanie własne na podstawie danych Eurostatu (http://ec.europa.eu/eurostat, data dostępu: 12.09.2016).

korektę. W latach 2008-2015 pozycja Chorwacji i Słowenii względem średniej UE pogorszyła się, a pozostałe państwa awansowały, lecz w bardzo różnym stopniu: najmniej Republika Czeska (2 pkt proc.), najwięcej Polska i Rumunia (po 16 pkt proc.). Kryzys odwrócił zatem proces niwelowania nierówności rozwojowych, jaki miał miejsce w EŚW od końca lat 90. i spowodował ich znaczne pogłębienie, przyczyniając się do osłabienia kruchej stabilności makroekonomicznej na tym obszarze ${ }^{4}$.

Analizując proces rozwojowy w długim okresie 1995-2015, należy stwierdzić, że EŚW na ogół dobrze wykorzystała zaistniałe w tym czasie warunki do zmniejszenia dystansu dzielącego ją od Europy Zachodniej i tym samym do poprawy swojej międzynarodowej pozycji konkurencyjnej. Proces konwergencji objął w tym okresie wszystkie bez wyjątku państwa EŚSW, ale w różnym stopniu. W najmniejszym stopniu w kierunku średniej UE przesunęła się Chorwacja (8 pkt proc.), w największym wspominane już kilkakrotnie państwa bałtyckie:

\footnotetext{
4 Jak zauważył noblista J.E. Stiglitz: „Po globalnym kryzysie finansowym z 2008 r. na świecie panuje coraz większa zgoda co do tego, że nierówności prowadzą do niestabilności i że niestabilność przyczynia się do nierówności” [2015, s. 190].
} 
Litwa (40 pkt proc.), Estonia (36 pkt proc.), Łotwa (33 pkt proc.). Awans Polski o 27 pkt proc. także zasługuje na bardzo pozytywną ocenę.

Tabela 6. Prognozowane wskaźniki wzrostu PKB w państwach Europy Środkowo-Wschodniej na tle świata i Unii Europejskiej (w \%)

\begin{tabular}{|l|c|c|c|c|c|}
\hline Wyszczególnienie & 2016 & 2017 & 2018 & 2019 & 2020 \\
\hline Świat & 3,1 & 3,4 & 3,6 & 3,7 & 3,7 \\
\hline UE & 1,9 & 1,7 & 1,8 & 1,8 & 1,8 \\
\hline Bułgaria & 3,0 & 2,8 & 2,5 & 2,5 & 2,5 \\
\hline Chorwacja & 1,9 & 2,1 & 2,2 & 2,3 & 2,3 \\
\hline Estonia & 1,5 & 2,5 & 2,9 & 3,1 & 3,2 \\
\hline Litwa & 2,6 & 3,0 & 3,3 & 3,6 & 3,6 \\
\hline Łotwa & 2,5 & 3,4 & 3,7 & 3,9 & 3,9 \\
\hline Polska & 3,1 & 3,4 & 3,3 & 3,1 & 3,0 \\
\hline Republika Czeska & 2,5 & 2,7 & 2,4 & 2,2 & 2,2 \\
\hline Rumunia & 5,0 & 3,8 & 3,3 & 3,3 & 3,3 \\
\hline Słowacja & 3,3 & 3,3 & 3,7 & 3,8 & 3,7 \\
\hline Słowenia & 2,3 & 1,8 & 1,6 & 1,6 & 1,6 \\
\hline Węgry & 2,0 & 2,4 & 2,4 & 2,2 & 2,1 \\
\hline
\end{tabular}

Źródło: opracowanie własne na podstawie [Uneven Growth... 2015].

Prognozy dotyczące zmian sytuacji ekonomicznej w najbliższej przyszłości nie napawają optymizmem (zob. tabela 6). Według Międzynarodowego Funduszu Walutowego słaba koniunktura w skali świata będzie się nieznacznie poprawiać, lecz w UE ustabilizuje się na poziomie ok. 1,8\% rocznie. W EŚSW wzrost PKB będzie natomiast wyraźnie szybszy niż w UE. Spośród państw tego regionu tylko Słowenia odnotuje wskaźniki wzrostu nieco gorsze od przeciętnych dla całej UE.

\section{Zmiany liczby ludności oraz wskaźników rynku pracy}

W ostatnich dwóch dekadach w EŚW zachodzą niepokojące zjawiska demograficzne: ludność się starzeje, spada przyrost naturalny, występuje duża emigracja zarobkowa. W konsekwencji tych zjawisk liczba ludności spada, a jej udział w populacji światowej systematycznie maleje: na progu transformacji gospodarczej w 1990 r. wynosił on 2,02\%, w 1995 r. - 1,87\%, 2000 r. - 1,76\%, 2008 r. - 1,60\%, 2015 r. - tylko 1,45\%. W ostatnich latach w związku z globalnym kryzysem finansowym i następującym po nim okresie destabilizacji i dekoniunktury gospodar- 
czej proces depopulacji EŚW uległ przyspieszeniu. W latach 2008-2014 liczba ludności w tej grupie państw zmniejszyła się o 2,5 mln osób, tj. o 2,4\%, podczas gdy w całej UE wzrosła o 6,5 mln osób, czyli o 1,3\%. Proces depopulacji był najbardziej zaawansowany na Litwie i Łotwie; w każdym z tych państw liczba ludności spadła aż o ponad 8\%. W tym czasie tylko trzy państwa: Republika Czeska, Słowacja i Słowenia, zdołały nieco zwiększyć swoje zaludnienie. W Polsce zjawisko to także wystąpiło, chociaż w niewielkim stopniu - populacja zmniejszyła się o 98 tys. osób, czyli o 0,28\% stanu wyjściowego. Prognozy demograficzne przewidują, że niekorzystne dla EŚW tendencje będą się utrzymywać. Według Eurostatu ${ }^{5}$ ludność EŚW będzie liczyć: w 2030 r. - 100 mln (96,5\% stanu z początku 2014 r.), w 2050 r. - 94,3 mln (91,0\%), w 2080 r. - 74,7 mln (72,1\%). Oznacza to, że procentowy udział ludności EŚW w stosunku do UE będzie systematycznie spadać: z 20,4\% w 2014 r. do 19,3\% w 2030 r., 17,9\% w 2050 r. i 14,4\% w 2080 r. Według tej prognozy proces depopulacji nasili się również w Polsce, gdzie liczba ludności spadnie z 38,1 mln w 2014 r. do 37,5 mln w 2030 r., 34,8 mln w 2050 r. i 29,6 mln w 2080 r. Rezultaty tego procesu będą niewątpliwie oddziaływać negatywnie na konkurencyjność międzynarodową.

Zmianom liczby i struktury ludności towarzyszyły zmiany sytuacji na rynku pracy. W okresie przedkryzysowym zatrudnienie w całej UE i w EŚS systematycznie rosło, lecz w latach kryzysu tendencja ta uległa odwróceniu. Pod tym względem w poszczególnych państwach EŚW sytuacja również była zróżnicowana; najtrudniejsza na Łotwie, gdzie w 2009 r. zatrudnienie zmniejszyło się aż o 13,2\%. Ze zmianami liczby zatrudnionych skorelowane są zmiany stopy zatrudnienia (tabela 7). Przed kryzysem globalnym bardzo korzystną tendencją był wzrost tego ważnego dla rynku pracy wskaźnika, który zarówno w całej UE, jak i w EŚW osiągnął maksimum w 2008 r. Następnie stopa zatrudnienia wyraźnie się obniżyła, by w ostatnich latach analizowanego okresu ponownie wzrosnąć, nie dochodząc jednak do stanu sprzed kryzysu. Pozytywnymi wyjątkami były: Polska, Republika Czeska, Rumunia i Węgry, w których stopa zatrudnienia już w 2014 r. była wyższa niż w 2008 r.

Zmianom w zatrudnieniu towarzyszyły przeciwstawne zmiany bezrobocia (zob. tabela 8). W latach przedkryzysowych wskaźnik bezrobocia w UE i w EŚW systematycznie się obniżał, dochodząc w 2008 r. do poziomu minimalnego. Państwom EŚW udało się w tym czasie znacznie zredukować wskaźniki bezrobocia (w Polsce stopa bezrobocia spadła z 20\% w 2002 r. do 7,1\% w 2008 r.). W okresie kryzysu sytuacja na rynkach pracy całej UE, w tym również w EŚW, znacznie się jednak pogorszyła. Niewątpliwie bezrobocie stanowiło jeden z najgorszych

${ }^{5} \mathrm{http}$ ://appsso.eurostat.ec.europa.eu/nui/show.do?dataset=proj_13npms\&lang=en (data dostępu: 29.12.2016). 
Tabela 7. Stopa zatrudnienia w państwach Europy Środkowo-Wschodniej na tle Unii Europejskiej* (w \%)

\begin{tabular}{|l|c|c|c|c|c|c|c|c|c|}
\hline Wyszczególnienie & 2007 & 2008 & 2009 & 2010 & 2011 & 2012 & 2013 & 2014 & 2015 \\
\hline UE & 69,8 & 70,3 & 68,9 & 68,6 & 68,6 & 68,4 & 68,4 & 69,2 & 70,1 \\
\hline Bułgaria & 68,4 & 70,7 & 68,8 & 65,4 & 62,9 & 63,0 & 63,5 & 65,1 & 67,1 \\
\hline Chorwacja & 63,9 & 64,9 & 64,2 & 62,1 & 59,8 & 58,1 & 57,2 & 59,2 & 62,9 \\
\hline Estonia & 76,9 & 77,1 & 70,0 & 66,8 & 70,6 & 72,2 & 73,3 & 74,3 & 76,5 \\
\hline Litwa & 72,7 & 72,0 & 67,0 & 64,3 & 66,9 & 68,5 & 69,9 & 71,8 & 73,3 \\
\hline Łotwa & 75,2 & 75,4 & 66,8 & 64,3 & 66,3 & 68,1 & 69,7 & 70,7 & 72,5 \\
\hline Polska & 62,7 & 65,0 & 64,9 & 64,3 & 64,5 & 64,7 & 64,9 & 66,5 & 67,8 \\
\hline Republika Czeska & 72,0 & 72,4 & 70,9 & 70,4 & 70,9 & 71,5 & 72,5 & 73,5 & 74,8 \\
\hline Rumunia & 64,4 & 64,4 & 63,5 & 64,8 & 63,8 & 64,8 & 64,7 & 65,7 & 66,0 \\
\hline Słowacja & 67,2 & 68,8 & 66,4 & 64,6 & 65,0 & 65,1 & 65,0 & 65,9 & 67,7 \\
\hline Słowenia & 72,4 & 73,0 & 71,9 & 70,3 & 68,4 & 68,3 & 67,2 & 67,8 & 69,1 \\
\hline Węgry & 62,3 & 61,5 & 60,1 & 59,9 & 60,4 & 61,6 & 63,0 & 66,7 & 68,9 \\
\hline
\end{tabular}

* Stopa zatrudnienia rozumiana jako udział pracujących w ogólnej liczbie ludności w wieku 20-64 lat.

Źródło: opracowanie własne na podstawie danych Eurostatu (http://ec.europa.eu/eurostat/data/ database, data dostępu: 12.09.2016).

Tabela 8. Zharmonizowana stopa bezrobocia w państwach Europy Środkowo-Wschodniej na tle Unii Europejskiej* (w \%)

\begin{tabular}{|l|c|c|c|c|c|c|c|c|c|}
\hline Wyszczególnienie & 2007 & 2008 & 2009 & 2010 & 2011 & 2012 & 2013 & 2014 & 2015 \\
\hline UE & 7,2 & 7,0 & 9,0 & 9,6 & 9,7 & 10,5 & 10,9 & 10,2 & 9,4 \\
\hline Bułgaria & 6,9 & 5,6 & 6,8 & 10,3 & 11,3 & 12,3 & 13,0 & 11,4 & 9,2 \\
\hline Chorwacja & 9,9 & 8,6 & 9,2 & 11,7 & 13,7 & 16,0 & 17,3 & 17,3 & 16,3 \\
\hline Estonia & 4,6 & 5,5 & 13,5 & 16,7 & 12,3 & 10,0 & 8,6 & 7,4 & 6,2 \\
\hline Litwa & 4,3 & 5,8 & 13,8 & 17,8 & 15,4 & 13,4 & 11,8 & 10,7 & 9,1 \\
\hline Łotwa & 6,1 & 7,7 & 17,5 & 19,5 & 16,2 & 15,0 & 11,9 & 10,8 & 9,9 \\
\hline Polska & 9,6 & 7,1 & 8,1 & 9,7 & 9,7 & 10,1 & 10,3 & 9,0 & 7,5 \\
\hline Republika Czeska & 5,3 & 4,4 & 6,7 & 7,3 & 6,7 & 7,0 & 7,0 & 6,1 & 5,1 \\
\hline Rumunia & 6,4 & 5,6 & 6,5 & 7,0 & 7,2 & 6,8 & 7,1 & 6,8 & 6,8 \\
\hline Słowacja & 11,2 & 9,6 & 12,1 & 14,5 & 13,7 & 14,0 & 14,2 & 13,2 & 11,5 \\
\hline Słowenia & 4,9 & 5,4 & 5,9 & 7,3 & 8,2 & 8,9 & 10,1 & 9,7 & 9,0 \\
\hline Węgry & 7,4 & 7,8 & 10,0 & 11,2 & 11,0 & 11,0 & 10,2 & 7,7 & 6,8 \\
\hline
\end{tabular}

* Zharmonizowana stopa bezrobocia rozumiana jako udział liczby bezrobotnych w ogólnej liczbie osób aktywnych zawodowo w wieku 15-74 lat.

Źródło: opracowanie własne na podstawie danych Eurostatu (http://ec.europa.eu/eurostat/data/ database, data dostępu: 12.09.2016). 
skutków kryzysu, według niektórych ekonomistów bardziej niepokojący niż wzrost deficytu budżetowego i długu publicznego ${ }^{6}$.

Zmiany na rynkach pracy w poszczególnych państwach EŚW były bardzo zróżnicowane. Największy spadek zatrudnienia i jednoczesny wzrost bezrobocia wystąpił w tych gospodarkach, w których najbardziej obniżył się PKB. Przede wszystkim były to państwa bałtyckie, a później Chorwacja. Najtrudniejsza, dramatyczna sytuacja panowała na Łotwie, gdzie w latach 2008-2010 stopa zatrudnienia spadła o 11,1 pkt proc. (w samym tylko 2009 r. o 8,6 pkt proc.), a jednocześnie stopa bezrobocia wzrosła o 11,8 pkt proc. (tylko w 2009 r. o 9,8 pkt proc.). Trzeba jednak podkreślić, że państwom tym udało się sytuację poprawić, szczególnie Estonii, która zdołała obniżyć stopę bezrobocia z 16,7\% w 2010 r. do 6,2\% w 2015 r. Nie udało się to natomiast najmłodszemu członkowi UE Chorwacji. Tradycyjnie niskie bezrobocie odnotowano pomimo kryzysu w Republice Czeskiej. Z tego samego powodu zwraca uwagę Rumunia, gdzie recesja gospodarcza trwała długo, lecz zmiany zatrudnienia i bezrobocia były niewielkie. Polska, w której recesji w ogóle nie było, odnotowała znikomy spadek stopy zatrudnienia (został już przezwyciężony) i równie niewielki wzrost bezrobocia.

\section{Konkluzje}

Zaprezentowana w artykule analiza potwierdziła przyjętą na wstępie hipotezę. Z przeprowadzonego badania wynika jednoznacznie, że konsekwencje globalnego kryzysu dla regionu EŚSW, podobnie jak dla całej UE, były negatywne, lecz bardzo zróżnicowane w poszczególnych państwach - do tego stopnia, że niektóre z nich poprawiły swoją pozycję względem pozostałych państw Wspólnoty, podczas gdy pozycja innych się pogorszyła. Podstawową przyczyną tych zmian był spadek dynamiki wzrostu gospodarczego. Zjawisko to wystąpiło jednak z różną siłą i w sposób bardzo nierównomierny, zarówno w czasie, jak i w przestrzeni. W okresie kryzysu najbardziej pozytywnie wyróżniły się te państwa, które poprzednio odnosiły sukcesy w stopniu raczej ograniczonym. Wśród nich należy wymienić przede wszystkim Polskę, która w tym czasie znacznie zmniejszyła swoją lukę rozwojową. Fakty te potwierdzają znaną z literatury hipotezę, że: „rosnąca międzynarodowa konkurencyjność Polski jest nie tylko konsekwencją

${ }^{6}$ Uważa tak m.in. noblista P. Krugman. Według niego, ,gdy miliony potencjalnych pracowników nie mają pracy i marnowany jest ekonomiczny potencjał wartości ok. 1 bln dolarów rocznie [w USA - uwaga autora], potrzebujemy polityków, którzy będą pracować nad szybkim ożywieniem, a nie ludzi, którzy robią wykład o potrzebie długookresowej stabilności finansów publicznych" [Lubowski 2011]. 
szybkiego wzrostu gospodarczego, ale także wyjątkowo dużej - jak dotąd odporności polskiej gospodarki na wstrząsy wewnętrzne i zewnętrzne" [Rapacki 2011, s. 26].

Jednocześnie okazało się, że analizowany region jest bardzo wrażliwy na tzw. szoki zewnętrzne. Załamanie koniunktury nastąpiło tutaj jeszcze przed spektakularnym bankructwem amerykańskiego Lehman Brothers (15 września 2008 r.). Dowodzi tego przykład państw bałtyckich, które w stan recesji weszły już na początku 2008 r. i później odnotowały bardzo duże spadki PKB, rekordowe w skali Wspólnoty i jedne z największych w skali świata. Wynika stąd, że EŚW, do niedawna uważana za region peryferyjny, jest już bardzo powiązana z globalnym systemem gospodarczym.

Odpowiedzią Unii Europejskiej, a w jej ramach EŚW, na wyzwania wynikające z wahań światowej koniunktury powinno być dalsze, mozolne umacnianie spójności gospodarczej i społecznej. Analizy makroekonomiczne dowodzą, że niwelowanie nierówności rozwojowych stabilizuje gospodarkę, sprzyja dynamice wzrostu gospodarczego i poprawia konkurencyjność międzynarodową. Dla Unii wynika stąd potrzeba zmniejszenia dysproporcji w rozwoju gospodarczym poszczególnych państw członkowskich. Budowa spójności społecznej i gospodarczej jest dla Wspólnoty zadaniem niezwykle istotnym, ponieważ od niej w dużym stopniu zależeć będzie ostateczne przezwyciężenie skutków omawianego kryzysu.

Na ogół uważa się, że głównym czynnikiem poprawy koniunktury jest wzrost popytu wewnętrznego. Może on być spowodowany spadkiem cen dóbr i usług, wzrostem dochodów ludności, zwiększonym popytem na pracę, a także zmianami w polityce gospodarczej i społecznej. W niektórych państwach (Polska, Republika Czeska, Słowacja, Rumunia) miał miejsce szybki wzrost nakładów inwestycyjnych, do czego przyczyniły się środki wsparcia z UE. Na gospodarkę EŚSW pozytywnie oddziałuje także poprawa koniunktury w państwach tzw. starej UE (zwłaszcza w Niemczech) i wynikające z niej ożywienie popytu zagranicznego.

Na szczególną uwagę zasługuje wpływ kryzysu globalnego na rynek pracy. Przedstawiona w niniejszym artykule analiza dowodzi, że perturbacje na tym rynku mogą wystąpić z pewnym opóźnieniem w stosunku do recesji gospodarczej. Wydarzenia ostatnich lat wskazują na to, że duże dysproporcje na rynku pracy mogą stanowić bardziej istotną barierę rozwojową niż nadmierny dług publiczny. Wielu ekonomistów wydaje się jednak tego nie dostrzegać, analizując skutki recesji przede wszystkim od strony finansów publicznych.

W EŚS, podobnie jak w całej UE, ciągle obecny jest pogląd, według którego najbardziej efektywnym instrumentem rozwiązywania problemów rynku pracy i w ogóle rozwoju społecznego jest dynamiczny wzrost gospodarczy. Współczesna rzeczywistość tego jednak nie potwierdza. Wydaje się w związku z tym, że inter- 
wencję antykryzysową należałoby ukierunkować nie tylko na wzrost PKB, lecz w nie mniejszym stopniu na równoważenie rynku pracy.

Należy podkreślić, że zmiany zachodzące w gospodarkach EŚSW odznaczają się tak dużą dynamiką, że wszelkie prognozy ich dotyczące są bardzo niepewne i obejmują w zasadzie tylko kilka najbliższych lat. Większość analityków oczekuje kontynuacji ożywienia gospodarczego z lat 2014-2016. Sprzyjać temu będzie spodziewany dalszy wzrost popytu wewnętrznego oraz eksportu, a także zwiększenie nakładów inwestycyjnych w sektorze prywatnym.

\section{Literatura}

Giddens A. [2014], Turbulent and Mighty Continent. What Future for Europe?, Polity Press, Cambridge.

The Impact of the Financial Crisis on the Central and Eastern European Countries [2010], ,Monthly Bulletin”, European Central Bank, July.

Kosiedowski W. [2008], Regiony Europy Środkowo-Wschodniej w procesie integracji, Wydawnictwo Naukowe Uniwersytetu Mikołaja Kopernika, Toruń.

Lubowski A. [2011], O człowieku, który długowi w pas się kłania, „Gazeta Wyborcza” z 22.08.2011.

Rapacki R. [2011], Wzrost gospodarczy i realna konwergencja [w:] Polska: raport o konkurencyjności 2011, red. M.A. Weresa, Oficyna Wydawnicza SGH, Warszawa.

Recession in the EU-27: Output Measures [2009], ,Statistics in Focus”, nr 17.

Soros G. [2009], The Crash of 2008 and What It Means: The New Paradigm for Financial Markets, Public Affairs, New York.

Stiglitz J.E. [2015], Cena nierówności. W jaki sposób dzisiejsze podziały społeczne zagrażajq naszej przyszłości?, Wydawnictwo Krytyki Politycznej, Warszawa.

Sytuacja gospodarcza w krajach Europy Środkowej i Wschodniej [2016], nr 1 i 2, Instytut Ekonomiczny NBP, Warszawa.

Transition Report 1999. Ten Years of Transition [1999], EBRD, London.

Uneven Growth: Short- and Long-Term Factors [2015], World Economic Outlook, April, www.imf.org (data dostępu: 12.09.2016).

\section{The Economy of Central and Eastern Europe during the Global Economic Crisis}

(Abstract)

The article discusses the course and results of the process of economic development of Central and Eastern Europe (CEE) in the context of integration with the European Union, with a particular emphasis on conditions connected with the global financial crisis. In the study the CEE economy was characterised against the background of the world and Europe, followed by a presentation and interpretation of the changes in dynamics of economic growth. It was found that these changes were strongly correlated. The text also presents the evolution of the situation on the labour market during the crisis. 
The article ends with synthetic conclusions from the analyses. The research proves that the process of economic convergence occurred in all CEE countries, which was a positive effect of EU cohesion policy. This process was, however, very diverse, and the global crisis brought about far-reaching, uneven changes, including even a few cases of divergence.

Keywords: Central and Eastern Europe, the European Union, global financial crisis, recession, economic growth, cohesion. 